\title{
Haemorrhagic shock encephalopathy syndrome in the British Isles
}

\author{
C J Bacon, S M Hall
}

\begin{abstract}
The aetiopathogenesis of haemorrhagic shock encephalopathy syndrome (HSES) remains unclear and after concern that a novel environmental agent was the cause, the British Paediatric Association and the Public Health Laboratory Service Communicable Disease Surveillance Centre in 1983 initiated surveillance of this condition in the British Isles. After 1986 cases were ascertained via the British Paediatric Surveillance Unit 'active' reporting scheme; this report presents the findings for 1985-8.

Sixty five patients were reported, of whom 52 satisfied the criteria for inclusion. Of those whose outcome was known, 24 (46\%) died, 18 had severe neurological damage, and six survived apparently intact. Epidemiological features of note were: the median age of 15 weeks (range 3-140); statistically significant clustering of admission times suggesting a peak onset period at night; lack of geographic clusters, of secular trends and, except for a slight excess in winter months, of seasonality.

Clinical and pathological features followed a highly consistent pattern, suggesting that HSES is an individual clinical entity distinguishable from conditions with similar presentations, such as septicaemia and Reye's syndrome.

There was no microbiological or epidemiological evidence to support the emergence of a novel environmental agent. Many of the features of HSES were, however, the same as those described in heat stroke and we suggest that the two conditions are the same even though there is usually no history of overt overheating.
\end{abstract}

\section{(Arch Dis Child 1992;67:985-993)}

Haemorrhagic shock encephalopathy syndrome (HSES) is a rare but devastating disorder of young children. It was first presented as a clinical entity under this name by Levin et al who in 1983 described 10 cases in the UK, ${ }^{1}$ although series from France and England describing patients with a similar constellation of clinical features had appeared earlier. ${ }^{2}{ }^{3}$ Subsequently, over a hundred cases of HSES have been reported in the world literature: from the Netherlands, ${ }^{4}$ Spain, ${ }^{5}$ Belgium, ${ }^{6}$ France, ${ }^{7}$ Germany, ${ }^{89}$ Portugal, ${ }^{10}$ New Zealand, ${ }^{11}$ Israel, ${ }^{12}$ the United States, ${ }^{13-18}$ the Far East, ${ }^{19} 20$ and further cases in the UK. ${ }^{21-26}$

After concerns that HSES might be a new disease caused by a novel environmental agent, the Public Health Laboratory Service Communicable Disease Surveillance Centre (CDSC) and the British Paediatric Association (BPA) set up a joint surveillance scheme in the British Isles. The results for $1982-4$ have been reported ${ }^{26}$ and we now present the findings for 1985-8, after which surveillance was discontinued. During this second period information was collected in greater detail so that the features of HSES could be delinated more fully, with the object of assisting the diagnosis and elucidating the aetiopathogenesis.

\section{Methods}

CASE DEFINITION

Clinicians were given the following guidelines but were asked to report even if all nine criteria were not met. A child had to be under 16 years of age with acute onset of: (1) encephalopathy, (2) shock, (3) disseminated intravascular coagulation, (4) diarrhoea (may be bloody), (5) falling haemoglobin concentration and platelet counts, (6) acidosis, (7) raised hepatocellular enzymes, (8) renal function impairment, and (9) negative cultures of blood and cerebrospinal fluid.

The criterion that plasma ammonia concentration should be normal, used in the 1982-4 reports, had proved inconsistent ${ }^{26}$ so was discontinued for 1985-8.

For the analysis, patients were allocated to one of three groups:

(A) Definite HSES: all nine criteria satisfied.

(B) Probable HSES: either: (i) eight criteria satisfied but one not met or (ii) at least seven criteria satisfied but no information on the remainder.

(C) Indeterminate/not HSES: either: (i) insufficient information, or (ii) another diagnosis more likely, or (iii) presence of a preceding event which may have distorted the clinical course.

CASE ASCERTAINMENT AND DATA COLLECTION Between January 1985 and May 1986, cases were ascertained through 'passive' reporting by paediatricians throughout the British Isles as described previously. ${ }^{26}$ From June 1986 to December 1988, reporting changed to the 'active' system of the British Paediatric Surveillance Unit (BPSU). ${ }^{27}$ The initial report generated a request to review case notes both from the first hospital and, where appropriate, from the referral centre. Epidemiological, clinical, and laboratory data were transcribed on to a standard proforma.
Correspondence to: Dr Bacon.

Accepted 10 April 1992 


\section{Results}

A total of 65 patients was reported. Thirty two were classified as group A (definite HSES) and 20 as group $B$ (probable HSES). The remaining 13 (group C) consisted of: (i) insufficient information (two cases); (ii) alternative diagnosis (three cases: septicaemia, toxic shock syndrome, valproate toxicity) and (iii) preceding event (eight cases: head injury, severe dehydration, laparotomy, adenotonsillectomy, severe hypoglycaemia, respiratory arrest, cardiac arrest (two cases)).

The following analyses include only the 52 group A and B cases.

\section{EPIDEMIOLOGICAL FEATURES}

The secular trends were unremarkable: there were 11 cases in 1985 (some of whom were described in another series ${ }^{24}$ ); seven in 1986, 18 in 1987 , and 16 in 1988. The annual totals for the preceding three years had been 13,22 , and nine. ${ }^{26}$ Small numbers hamper interpretation of seasonality, but there were no clear trends either within each year or taking the period as a whole. However 29/52 (56\%) of the cases occurred in the winter quarters (the same proportion as in the 1982-4 cases) with the highest numbers occurring in January and February (eight and nine respectively).

As in the previous years, cases were reported throughout the British Isles with no obvious clustering in place or time. Eighteen of the 52 patients were referred to a tertiary care centre. The remainder were managed in their local district general hospitals.

The age range was 6 to 140 weeks (median 14.5) for group A and 3 to 86 (median 16) for group $B$. The mean age (SD) of the 52 cases as a whole was $19.8(21 \cdot 1)$ weeks and the median and mode 15 weeks and 13 weeks respectively. Fifty (96\%) patients were under 1 year of age. The male:female ratio was $14: 18$ for group $A$ and 13:7 for group $B$.

\section{CLINICAL FEATURES (TABLE 1)}

The 52 patients in groups $A$ and $B$ were clinically very similar and are considered together except where specified. Seven (13\%) had pre-existing developmental anomalies and other problems: of these, two aged 13 and 17 weeks, had had repairs of cleft lip and palate,

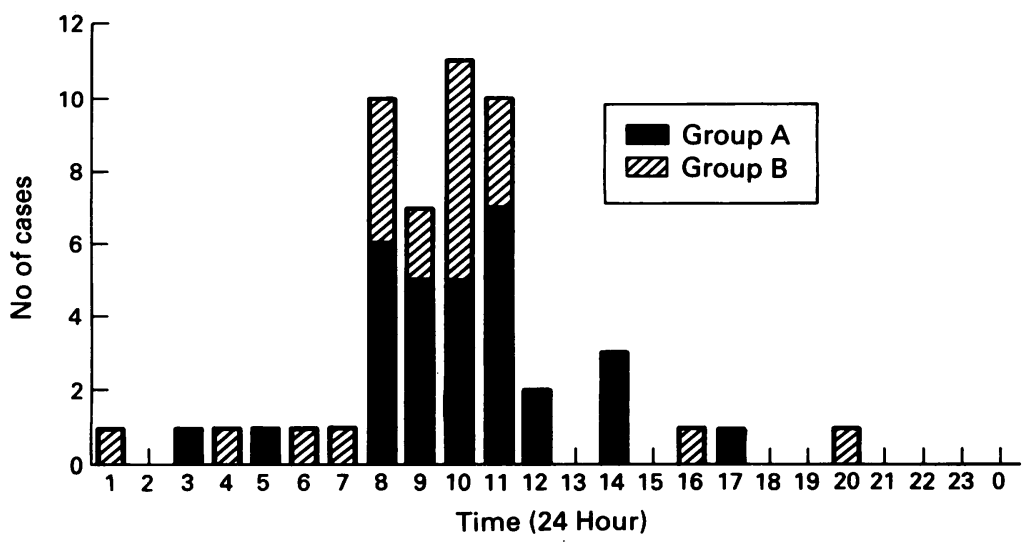

Time of admission to first hospital in HSES ( $n=51$, one baby not known).
Table 1 Clinical features. Results are number (\%)

\begin{tabular}{llll}
\hline & $\begin{array}{l}\text { Group } A \\
(n=32)\end{array}$ & $\begin{array}{l}\text { Group } B \\
(n=20)\end{array}$ & $\begin{array}{l}\text { Combined } \\
(n=52)\end{array}$ \\
\hline Abrupt onset & $32(100)$ & $20(100)$ & $52(100)$ \\
Prodromal illness & $19(59)$ & $12(60)$ & $31(60)$ \\
Admission temperature $>40^{\circ} \mathrm{C}$ & $18(56)$ & $9(45)$ & $27(52)$ \\
Circulatory collapse & $32(100)$ & $20(100)$ & $52(100)$ \\
Coma & $24(75)$ & $15(75)$ & $39(75)$ \\
Convulsions & $32(100)$ & $18(90)$ & $50(96)$ \\
Respiratory disturbance & $30(94)$ & $18(90)$ & $48(92)$ \\
Vomiting & $7(22)$ & $5(25)$ & $12(23)$ \\
Loose stools & $32(100)$ & $17(85)$ & $49(94)$ \\
Oliguria/anuria & $27(84)$ & $15(75)$ & $42(81)$ \\
Manifest bleeding tendency & $27(84)^{*}$ & $15(75)^{*}$ & $42(81)^{*}$ \\
Liver enlargement & $22(69)$ & $13(65)$ & $35(67)$ \\
& & & \\
Outcome: & $4(13)$ & $2(10)$ & $13(2)$ \\
$\quad$ Full recovery & $13(41)$ & $11(55)$ & $24(46)$ \\
Death & $14(44)$ & $4(20)$ & $18(35)$ \\
Neurological damage & $1(3)$ & $3(15)$ & $4(8)$ \\
$\quad$ Uncertain & &
\end{tabular}

${ }^{*}$ Five further cases in group $A$ and two in group $B$ had abnormal coagulation tests.

while a third aged 13 weeks had had a repair of a meningomyelocele; two others aged 48 and 36 weeks had spasticity and two aged 140 and 28 weeks had generalised delay. The mean (SD) age of the latter four babies was 63 (52) compared with 16 (12) weeks for the other 48 patients.

Thirty one patients had a mild prodromal illness with respiratory $(n=19)$ or gastrointestinal $(n=12)$ symptoms. The remainder had been well, although five had had recent contact with infection.

Three babies were each one of twins. In two of these cases (reported in detail elsewhere ${ }^{25}$ ) the other twin was found dead at the same time, the deaths being attributed to sudden infant death syndrome (SIDS).

The onset of the main illness was invariably abrupt and catastrophic. Although all the babies had been well or only mildly unwell when last seen (usually the previous night) most were found extremely ill in their cots first thing next morning; this characteristic timing was reflected in the clustering of admissions betwen 8 am and 11 am (figure); this clustering was unlikely to have occurred by chance $\left(\chi^{2}=75 \cdot 24,5 \mathrm{df}\right.$ $\mathrm{p}<0.001$ ).

All 20 babies whose condition when first found by the parents was recorded, were described as unusually hot or sweaty. The first recorded temperatures, taken at varying intervals after admission (methods varied and were inconsistently reported), indicated that most babies (42/49 with this information) were febrile. The modal temperature was $40-41^{\circ} \mathrm{C}$ and seven patients had a temperature $\geqslant 42^{\circ} \mathrm{C}$. Six had subnormal temperatures, one as low as $27^{\circ} \mathrm{C}$, but all had been stripped for some time before the recording. One baby had a normal temperature.

No patient was reported to have a rash. Conscious level on admission was recorded in 51 cases: 39 were comatose, 24 dying without regaining consciousness. The other 12 were semiconscious or poorly responsive. Fifty babies had convulsions of whom $35(67 \%)$ were fitting on admission and $\mathbf{1 0}$ more began to fit within a few hours. Convulsions were usually generalised or multifocal and difficult to control, especially if they had started early. Of the two babies in 
whom no fits were recorded, one died soon after admission and the other had been promptly paralysed for ventilation.

Vomiting was not a major feature; it occurred in only 12 cases and was not copious. Loose stools were noted in all cases except three, either at admission or within the next 10 hours; usually profuse, they were also bloody in 19 cases (37\%). Twenty one babies ( $40 \%)$ were assessed as dehydrated on admission, one severely so. Circulatory collapse ('shock') was present in all cases. The mean systolic blood pressure on admission, measured in 32 cases, was $58 \mathrm{~mm}$ $\mathrm{Hg}$ (range 0-99 $\mathrm{mm} \mathrm{Hg}$ ) and the mean pulse rate, 177/minute (range 110-250/minute). Progressive hepatomegaly, defined as a liver edge more than $2 \mathrm{~cm}$ below the costal margin, was recorded in two thirds of cases, reaching a maximum at about 24 hours, with the liver extending usually about $4 \mathrm{~cm}$, but in one case $9 \mathrm{~cm}$, below the costal margin.

Forty two babies $(81 \%)$ had anuria or oliguria. When urine was passed it usually contained protein and red blood cells. Three babies were dialysed and six others died anuric. In the 10 cases where oliguria was not documented the blood urea concentration was nevertheless raised.

Most babies had disturbed breathing patterns when first seen, respiration usually being rapid and shallow $(n=36)$ or sometimes very irregular $(n=12)$. There was no evidence of major pulmonary disorder and the respiratory disturbances appeared to be central. Thirty nine babies $(75 \%)$ required assisted ventilation, which was initiated sometimes for respiratory support and sometimes to control seizures and raised intracranial pressure. Ventilation was continued in some cases for up to seven days.

Forty two (81\%) babies demonstrated a bleeding tendency within the first 24 hours of admission, usually from the gastrointestinal tract, venepuncture sites, or an endotracheal tube. Among the remaining 10 patients, clotting tests were abnormal in the seven in whom they were performed.

\section{OUTCOME}

Twenty four babies died (46\%, 13 boys and 11 girls), $13(41 \%)$ in group $A$ and $11(55 \%)$ in group B. Some died within a few hours of admission and $19(37 \%)$ had succumbed by the

Table 2 Laboratory results

\begin{tabular}{|c|c|c|c|c|}
\hline & $\begin{array}{l}\text { Group } A \\
(n=32)\end{array}$ & $\begin{array}{l}\text { No of cases } \\
\text { investigated }\end{array}$ & $\begin{array}{l}\text { Group B } \\
(n=20)\end{array}$ & $\begin{array}{l}\text { No of cases } \\
\text { investigated }\end{array}$ \\
\hline $\begin{array}{l}\text { Fall in haemoglobin }(g / l) \\
\text { Lowest platelet count }\left(\times 10^{9} / 1\right) \\
\text { Initial white cell count }\left(\times 10^{9} / 1\right)\end{array}$ & $\begin{array}{l}\operatorname{Mean}(S D) \\
35 \cdot 0(16) \\
53 \cdot 00(24 \cdot 7) \\
22 \cdot 90(11 \cdot 1)\end{array}$ & $\begin{array}{l}32 \\
32 \\
31\end{array}$ & $\begin{array}{l}\operatorname{Mean}(S D) \\
33 \cdot 0(11 \cdot 0) \\
56 \cdot 00(26 \cdot 00) \\
24 \cdot 50(12 \cdot 40)\end{array}$ & $\begin{array}{l}16 \\
12 \\
20\end{array}$ \\
\hline $\begin{array}{l}\text { Initial sodium }(\mathrm{mmol} / \mathrm{l}) \\
\text { Initial bicarbonate }(\mathrm{mmol} / \mathrm{l}) \\
\text { Initial pH } \\
\text { Maximum blood urea }(\mathrm{mmol} / \mathrm{l})\end{array}$ & $\begin{array}{c}145 \cdot 00(4 \cdot 9) \\
11 \cdot 50(2 \cdot 5) \\
7 \cdot 16(0 \cdot 14) \\
17 \cdot 00(4 \cdot 9)\end{array}$ & $\begin{array}{l}31 \\
31 \\
26 \\
32\end{array}$ & $\begin{array}{c}146 \cdot 00(5 \cdot 50)^{*} \\
11 \cdot 40(2 \cdot 70) \\
7 \cdot 12(0 \cdot 16) \\
16 \cdot 20(4 \cdot 40)\end{array}$ & $\begin{array}{l}18 \\
17 \\
15 \\
16\end{array}$ \\
\hline $\begin{array}{l}\text { Blood glucose }<2 \mathrm{mmol} / \mathrm{l} \\
\text { Hepatic transaminases: abnormal } \\
\alpha_{1}-\text { Antitrypsin }<20 \mu \mathrm{mol} / \mathrm{l} \\
\text { Ammonia } \geqslant 100 \mu \mathrm{mol} / 1\end{array}$ & $\begin{array}{l}\text { No of cases } \\
23 \\
32 \\
5 \\
9\end{array}$ & $\begin{array}{l}29 \\
32 \\
12 \\
29\end{array}$ & $\begin{array}{l}\text { No of cases } \\
13 \\
18 \\
1 \\
5\end{array}$ & $\begin{array}{r}19 \\
18 \\
7 \\
16\end{array}$ \\
\hline
\end{tabular}

${ }^{*}$ Excluding one concentration of $122 \mathrm{mmol} / 1$. fourth day of the illness. Death within 48 hours was more common in group B (eight cases compared with two in group A) possibly because it prevented the emergence of all the diagnostic criteria. Outcome was related to severity of encephalopathy at presentation: babies with intractable convulsions and deep coma were likely to die, while those with less depressed consciousness and less frequent fits usually survived.

Of the 28 survivors, 18 had severe neurological damage, typically manifested by a fall-off in head growth, developmental regression, spasticity, cortical visual impairment, and seizures. In four babies the neurological outcome was uncertain, while six were deemed to have recovered. The mean duration of admission among survivors (excluding one child who stayed in hospital for seven months partly for social reasons) was 23 days (range 8-80 days) Early readmissions because of seizures were common.

\section{HAEMATOLOGICAL FEATURES (TABLE 2)}

Haemoglobin concentrations were normal at presentation in all patients, but in 47 of the 48 cases where successive measurements were made, fell by a mean of $36 \mathrm{~g} / \mathrm{l}$ (range 17-83 g/l) over the next 12-48 hours. Eighteen babies received a blood transfusion. Platelet counts were initially always normal or raised, but fell to a mean of approximately $54 \times 10^{9} / 1$ (minimum $16 \times 10^{9} / 1$ ) over a similar period. The initial white cell count was raised in every case except one, with a mean value of $23 \times 10^{9} / 1$ (range $7 \cdot 3-67 \cdot 3 \times 10^{9} / 1$ ). Either neutrophils or lymphocytes were reported to predominate, and in some cases neutrophils were immature. Coagulation tests, a wide variety of which were performed in all except four patients, were always abnormal, with an initially moderate disturbance becoming more severe by 24 hours.

\section{BIOCHEMICAL FEATURES (TABLE 2)}

All patients except two were initially hypernatraemic, with a mean serum sodium concentration of $145 \mathrm{mmol} / \mathrm{l}$ and a highest value of 156 $\mathrm{mmol} / \mathrm{l}$. All were acidotic, the mean serum bicarbonate being $11.5 \mathrm{mmol} / 1$ (minimum 6.9 $\mathrm{mmol} / \mathrm{l}$ ) and the mean arterial or capillary $\mathrm{pH}$ being $7 \cdot 16$ (minimum $6 \cdot 80$ ). Acidosis was often hard to correct. Blood urea was usually slightly raised on admission and always rose higher over the next 48 hours to a mean maximum concentration of $17.0 \mathrm{mmol} / \mathrm{l}$, the highest level being $29 \cdot 7 \mathrm{mmol} / \mathrm{l}$.

A progressive rise in hepatocellular enzymes was invariable, activities being moderately raised where assays were done early and grossly raised by 48-72 hours. Hypoglycaemia (blood glucose $<2 \mathrm{mmol} / \mathrm{l}$ ) was a common early feature, being recorded in $36(75 \%)$ of the 48 cases in whom the blood glucose was measured (this includes some measurements by reagent strips as well as laboratory assays). Hypoglycaemia was either present on admission (14 cases, 29\%) or developed over the next few hours (22 cases, $46 \%$ ). It was often profound, with recordings of 
zero in 14 cases, and difficult to correct by dextrose infusion. No insulin assays were performed.

Plasma ammonia concentrations were measured at least once in 45 children, 29 in group A and 16 in group B. Thirteen patients had concentrations below $50 \mu \mathrm{mol} / 1,18$ between 50 and $99 \mu \mathrm{mol} / 1$, and 14 had concentrations of $100 \mu \mathrm{mol} / \mathrm{l}$ or more, the highest being $328 \mu \mathrm{mol} / \mathrm{l}$. In eight of the cases where the ammonia was 100 $\mu \mathrm{mol} / \mathrm{l}$ or more, the sample had been taken within an hour of admission; in each of these eight the concentration had fallen below $100 \mu / 1$ within 24 hours. In five cases the timing of the raised concentration was not recorded; in one case it was recorded as normal on admission, but as $124 \mu \mathrm{mol} / 136$ hours later.

$\alpha_{1}$-Antitrypsin concentrations were available in 19 patients and were reduced $(<20 \mu \mathrm{mol} / \mathrm{l})$ in six, including all three in whom samples were taken in the first 12 hours. Only three recordings of immunereactive trypsin were available, all taken after 24 hours: two were normal and one appreciably raised $(>400 \mathrm{mg} / \mathrm{ml})$. Pi phenotyping was available on four surviving babies; three were $\mathrm{Pi} M M$ and one $\mathrm{Pi} \mathrm{MZ}$. Creatine phosphokinase was raised $(1886,1921$, and $4185 \mathrm{IU} / \mathrm{l}$ ) in three of the four cases in whom it was assayed, the samples being taken between

Table 3 Microbiological findings

\begin{tabular}{lccc}
\hline & $\begin{array}{l}\text { Group A } \\
(n=32)\end{array}$ & $\begin{array}{l}\text { Group B } \\
(n=20)\end{array}$ & $\begin{array}{l}\text { Combined } \\
(n=52)\end{array}$ \\
\hline $\begin{array}{l}\text { Blood culture } \\
\text { Performed }\end{array}$ & 32 & 18 & 50 \\
$\quad$ Positive & 7 & 8 & $15^{*}$ \\
$\begin{array}{l}\text { CSF culture } \\
\quad \begin{array}{l}\text { Performed } \\
\text { Positive }\end{array}\end{array}$ & 32 & 16 & 48 \\
$\begin{array}{l}\text { Stool culture (bacterial) } \\
\text { Performed } \\
\text { Positive }\end{array}$ & 2 & 0 & $2 \dagger$ \\
$\begin{array}{l}\text { Viral studies } \\
\text { (culture or serology) }\end{array}$ & 32 & 19 & 51 \\
$\quad$ Performed & 4 & 2 & $6 \ddagger$ \\
$\quad$ Positive & 23 & 12 & 35 \\
\hline
\end{tabular}

*Staphylococcus coagulase negative $(n=10)$, Staphylococcus coagulase positive $(\mathrm{n}=2)$, Streptococcus faecalis $(\mathrm{n}=1)$, Streptocoagulase positive $(\mathrm{n}=2)$, Streptococcus faecalis $(\mathrm{n}=1)$
coccus viridans $(\mathrm{n}=1)$, Moraxella catarrhalis $(\mathrm{n}=1)$

coccus viridans $(\mathrm{n}=1)$, Moraxella catarrhalis $(\mathrm{n}=1)$.
tStaphylococcus coagulase negative $(\mathrm{n}=1)$, Staphylococcus †Staphylococcus coagulase negative $(\mathbf{n}=1)$

coagulase positive (on enrichment) $(n=1)$. $\ddagger$ Clostridium difficile $(\mathbf{n}=3)$; pathogenic Escherichia coli $(\mathbf{n}=2)$; Gram positive cocci $(n=1)$.

Enterovirus (three including one coxsackie B5); adenovirus $(n=1)$; rotavirus $(n=1)$; parainfluenzae type $3(n=1)$.
24 and 72 hours after admission. Amylase was assayed in five cases (all within 24 hours of admission); it was raised in one (240 IU/l) and normal in the remainder $(68,78,131$, and 163 IU/l).

\section{MICROBIOLOGICAL FINDINGS (TABLE 3)}

Microbiological findings were inconsistent and of uncertain clinical relevance. The organisms grown from blood and cerebrospinal fluid (CSF) (15 cases and two cases respectively) were all regarded as contaminants by the clinicians concerned. No pleocytosis accompanied the two positive CSF cultures. However, in six other samples of CSF there was a small excess of lymphocytes, 7-16 cells being counted per $\mathrm{mm}^{3}$. In $12 \mathrm{CSF}$ samples the protein content was slightly raised, with a mean value (SD) of 79 (41) $\mathrm{g} / \mathrm{l}$

Stool specimens were cultured in 51 cases, of which six yielded possible pathogens. No significant infection was found in the 46 patients whose urine was cultured.

\section{RADIOLOGICAL FINDINGS}

Chest $x$ ray films were taken on 44 babies, usually after intubation. Abnormalities were seen in 15: collapse of an upper lobe (10 cases), streaky shadowing (two cases), underinflation of one lung (one case), aspiration (one case), and unspecified changes (one case). These appearances were thought by the relevant clinicians to be secondary rather than causative features of the illness.

\section{NEUROLOGICAL INVESTIGATIONS (TABLE 4)}

Electroencephalographic abnormalities of various kinds were found, focal or multifocal spike activity being the most common. Recordings made in the first 72 hours were abnormal in 22 of 23 patients; when 12 of these 22 were reexamined after an interval of a week or more, nine remained abnormal. Cranial ultrasonography was abnormal in 10 of the 24 patients investigated, with initial diminution of ventricular volume and subsequent asymmetry or atrophy of cerebral tissue. Computed tomography often showed diminution of ventricular volume initially and cerebral atrophy later; low density areas in the cortex were seen at all stages.

Table 4 Neurological investigations

\begin{tabular}{|c|c|c|c|c|c|c|}
\hline Time after presentation & Electroencephalography & & Cranial ultrasonography & & Cranial computed tomog & phy \\
\hline $\begin{array}{l}\text { Total patients investigated } \\
0-72 \text { hours }\end{array}$ & $\begin{array}{l}\text { Focal/multifocal spikes } \\
\text { Low amplitude activity } \\
\text { Slow waves } \\
\text { Flat } \\
\text { Unspecified abnormalities } \\
\text { Normal }\end{array}$ & $\begin{array}{r}23 \\
14 \\
4 \\
3 \\
3 \\
5 \\
1\end{array}$ & $\begin{array}{l}\text { Diminished ventricles } \\
\text { Normal }\end{array}$ & $\begin{array}{r}17 \\
7 \\
10\end{array}$ & $\begin{array}{l}\text { Diminished ventricles } \\
\text { Low density areas } \\
\text { Normal }\end{array}$ & $\begin{array}{r}10 \\
6 \\
3 \\
3\end{array}$ \\
\hline $\begin{array}{l}\text { Total patients investigated } \\
3-7 \text { days }\end{array}$ & $\begin{array}{l}\text { Low amplitude activity } \\
\text { Flat } \\
\text { Unspecified abnormalities }\end{array}$ & $\begin{array}{l}6 \\
2 \\
1 \\
3\end{array}$ & $\begin{array}{l}\text { Asymmetrical ventricles } \\
\text { Normal }\end{array}$ & $\begin{array}{l}4 \\
1 \\
3\end{array}$ & $\begin{array}{l}\text { Diminished ventricles } \\
\text { Low density areas }\end{array}$ & $\begin{array}{l}2 \\
1 \\
1\end{array}$ \\
\hline $\begin{array}{l}\text { Total patients investigated } \\
8-120 \text { days }\end{array}$ & $\begin{array}{l}\text { Focal/multifocal spikes } \\
\text { Slow waves } \\
\text { Hypsarrhythmia } \\
\text { Unspecified abnormalities } \\
\text { Normal }\end{array}$ & $\begin{array}{r}12 \\
5 \\
1 \\
1 \\
2 \\
3\end{array}$ & $\begin{array}{l}\text { Asymmetrical ventricles } \\
\text { Cerebral atrophy } \\
\text { Normal }\end{array}$ & $\begin{array}{l}3 \\
1 \\
1 \\
1\end{array}$ & $\begin{array}{l}\text { Low density areas } \\
\text { Cerebral atorphy }\end{array}$ & $\begin{array}{l}7 \\
3 \\
4\end{array}$ \\
\hline
\end{tabular}


Table 5 Postmortem findings

\begin{tabular}{|c|c|c|c|c|c|c|c|c|c|c|c|}
\hline \multirow{2}{*}{$\begin{array}{l}\text { Case } \\
\text { No }\end{array}$} & \multirow{2}{*}{$\begin{array}{l}\text { Duration of } \\
\text { illness } \\
\text { (hours) }\end{array}$} & \multicolumn{2}{|l|}{ Brain } & \multicolumn{2}{|l|}{ Lungs } & \multicolumn{2}{|l|}{ Liver } & \multicolumn{2}{|l|}{ Kidneys } & \multicolumn{2}{|l|}{ Adrenals } \\
\hline & & Gross & Histology & Gross & Histology & Gross & Histology & Gross & Histology & Gross & Histology \\
\hline \multirow{2}{*}{$\underset{1^{*}}{\text { Group A }}$} & & & & & & & & & & & \\
\hline & 102 & $\begin{array}{l}\text { Soft and } \\
\text { swollen, } \\
\text { herniation }\end{array}$ & NA & $\begin{array}{c}\text { Congestion, } \\
\text { patchy } \\
\text { haemorr- } \\
\text { hage }\end{array}$ & $\begin{array}{l}\text { Focal } \\
\text { haemorr- } \\
\text { hage }\end{array}$ & $\begin{array}{l}\text { Fatty, } \\
\text { 'nutmeg' } \\
\text { pattern }\end{array}$ & CLN & Congestion & Some ATN & Normal & $\begin{array}{l}\text { Medullary } \\
\text { congestion }\end{array}$ \\
\hline 2 & 71 & Swollen & $\begin{array}{l}\text { Zonal hypo- } \\
\text { xic damage }\end{array}$ & Congestion & NA & Normal & NA & Congestion & NA & Normal & NA \\
\hline 3 & 19 & $\begin{array}{l}\text { Soft and } \\
\text { swollen }\end{array}$ & NA & Congestion & NA & Pale & NA & Normal & NA & Normal & NA \\
\hline 4 & 65 & Swollen & NA & $\begin{array}{c}\text { Congestion, } \\
\text { patchy } \\
\text { collapse }\end{array}$ & Oedema & $\begin{array}{c}\text { Slightly pale } \\
\text { and fatty }\end{array}$ & $\begin{array}{l}\text { CLN, some } \\
\text { fatty } \\
\text { change }\end{array}$ & Swollen & Normal & Normal & NA \\
\hline 5 & 51 & $\begin{array}{l}\text { Soft and } \\
\text { swollen }\end{array}$ & NA & $\begin{array}{c}\text { Congestion, } \\
\text { patchy } \\
\text { haemorr- } \\
\text { hage }\end{array}$ & $\begin{array}{l}\text { Congestion, } \\
\text { intra- } \\
\text { alveolar } \\
\text { haemorr- } \\
\text { hage }\end{array}$ & $\begin{array}{l}\text { Enlarged and } \\
\text { fatty }\end{array}$ & CLN & Normal & $\begin{array}{l}\text { ATN } \\
\text { possible } \\
\text { chronic } \\
\text { glomerulo- } \\
\text { pathy }\end{array}$ & Normal & NA \\
\hline 6 & 52 & NA & NA & Congestion & $\begin{array}{l}\text { Focal } \\
\text { haemorr- } \\
\text { hage }\end{array}$ & $\begin{array}{l}\text { Not } \\
\text { enlarged, } \\
\text { mottled } \\
\text { red/brown }\end{array}$ & CLN & $\begin{array}{l}\text { Focal } \\
\text { pallor }\end{array}$ & $\begin{array}{c}\text { Some } \\
\text { ATN }\end{array}$ & $\begin{array}{l}\text { Some } \\
\text { haemorr- } \\
\text { hage }\end{array}$ & $\begin{array}{l}\text { Haemorr- } \\
\text { hage }\end{array}$ \\
\hline 7 & 56 & $\begin{array}{l}\text { Swollen, } \\
\text { herniation }\end{array}$ & $\begin{array}{c}\text { Hypoxic } \\
\text { damage }\end{array}$ & Congestion & $\begin{array}{l}\text { Congestion, } \\
\text { focal } \\
\text { haemorr- } \\
\text { hage }\end{array}$ & $\begin{array}{l}\text { Enlarged } \\
\text { irregular } \\
\text { pale areas }\end{array}$ & $\begin{array}{c}\text { Fatty change } \\
\text { (micro- } \\
\text { vesicular), } \\
\text { focal } \\
\text { necrosis } \\
\text { (not zonal) }\end{array}$ & Normal & Normal & Normal & Normal \\
\hline 8 & 76 & $\begin{array}{l}\text { Swollen, } \\
\text { herniation }\end{array}$ & Oedema & Congestion & Congestion & Normal & $\begin{array}{l}\text { Periportal } \\
\text { fatty } \\
\text { change }\end{array}$ & Normal & Congestion & Normal & Normal \\
\hline 9 & 72 & Soft & $\begin{array}{c}\text { Hypoxic } \\
\text { damage }\end{array}$ & $\begin{array}{l}\text { Congestion, } \\
\text { focal } \\
\text { haemorr- } \\
\text { hage }\end{array}$ & $\begin{array}{l}\text { Intra- } \\
\quad \text { alveolar } \\
\text { haemorr- } \\
\text { hage }\end{array}$ & $\begin{array}{l}\text { Enlarged } \\
\text { and fatty }\end{array}$ & $\begin{array}{c}\text { CLN, fatty } \\
\text { change }\end{array}$ & Pale & $\begin{array}{l}\text { Fatty } \\
\text { infiltration } \\
\text { of tubular } \\
\text { epithelium }\end{array}$ & Normal & NA \\
\hline 10 & 29 & $\begin{array}{l}\text { Swollen, } \\
\text { herniation }\end{array}$ & NA & $\begin{array}{l}\text { Patchy } \\
\text { collapse }\end{array}$ & $\begin{array}{l}\text { Some } \\
\text { oedema, } \\
\text { intra- } \\
\text { alveolar } \\
\text { haemorr- } \\
\text { hage }\end{array}$ & $\begin{array}{l}\text { Pale and } \\
\text { fatty }\end{array}$ & $\begin{array}{c}\text { Diffuse fatty } \\
\text { change } \\
\text { (micro- } \\
\text { vesicular) }\end{array}$ & Normal & $\begin{array}{c}\text { A few cystic } \\
\text { tubules }\end{array}$ & Normal & Normal \\
\hline \multirow{2}{*}{$\underset{1}{\text { Group B }}$} & & & & & & & & & & & \\
\hline & 35 & $\begin{array}{l}\text { Soft, } \\
\text { ?infarction }\end{array}$ & $\begin{array}{c}\text { Haemorr- } \\
\text { hagic } \\
\text { changes }\end{array}$ & $\begin{array}{c}\text { Congestion, } \\
\text { haemorr- } \\
\text { hage }\end{array}$ & Congestion & $\begin{array}{l}\text { Pale, } \\
\text { mottled }\end{array}$ & $\begin{array}{l}\text { Inter- } \\
\text { sinusoidal } \\
\text { haemorr- } \\
\text { hagic } \\
\text { changes }\end{array}$ & Congestion & NA & $\begin{array}{l}\text { Haemorr- } \\
\text { hage, } \\
\text { infarction }\end{array}$ & Infarction \\
\hline 2 & 56 & $\begin{array}{l}\text { Swollen, } \\
\text { herniation }\end{array}$ & NA & Normal & NA & $\begin{array}{l}\text { Partly } \\
\text { yellow } \\
\text { discolour- } \\
\text { ation }\end{array}$ & NA & Congestion & NA & Normal & NA \\
\hline $3 t$ & 7 & Normal & NA & Congestion & NA & $\begin{array}{l}\text { ?Fatty } \\
\text { change }\end{array}$ & NA & Normal & NA & NA & NA \\
\hline 4 & 8 & $\begin{array}{l}\text { Congestion, } \\
\text { focal } \\
\text { haemorr- } \\
\text { hage }\end{array}$ & $\begin{array}{l}\text { Micro- } \\
\text { thrombi, } \\
\text { micro- } \\
\text { infarction }\end{array}$ & $\begin{array}{l}\text { Focal } \\
\text { haemorr- } \\
\text { hage, } \\
\text { ?pneum- } \\
\text { onitis }\end{array}$ & Congestion & Congestion & $\begin{array}{l}\text { Congestion, } \\
\text { no fatty } \\
\text { change }\end{array}$ & Normal & Congestion & $\begin{array}{l}\text { Haemorr- } \\
\text { hage, } \\
\text { infarction }\end{array}$ & Infarction \\
\hline 5 & 12 & Normal & NA & $\begin{array}{c}\text { Congestion, } \\
\text { haemorr- } \\
\text { hage }\end{array}$ & Congestion & Normal & Congestion & Normal & Normal & Congestion & Congestion \\
\hline 6 & 120 & Swollen & $\begin{array}{l}\text { Focal } \\
\text { lympho- } \\
\text { cytic } \\
\text { infiltration }\end{array}$ & $\begin{array}{l}\text { Patchy } \\
\text { broncho- } \\
\text { pneu- } \\
\text { monia }\end{array}$ & Congestion & Yellow & $\begin{array}{l}\text { Centrilobular } \\
\text { congestion, } \\
\text { cholestasis }\end{array}$ & Normal & Normal & $\begin{array}{l}\text { Swollen, } \\
\text { haemorr- } \\
\text { hage }\end{array}$ & Normal \\
\hline
\end{tabular}

*Also pituitary necrosis, falso haemorrhagic colitis.

ATN = acute tubular necrosis, $\mathrm{CLN}=$ centrilobular necrosis, $\mathrm{NA}=$ not available

The sequence of changes found in these three investigations suggests an intial and severe generalised cerebral disturbance leading on quickly to cerebral oedema, and then sometimes to infarction and atrophy. Further evidence for an extreme rise in intracranial pressure was provided by a case in which brain tissue was extruded through a monitoring catheter.

POSTMORTEM FINDINGS (TABLE 5)

Necropsy reports were available for 10 of the 13 fatal cases in group A and for six of the 11 fatal cases in group B. A seventh group B patient had an immediate postmortem liver biopsy, but no necropsy.

Small focal haemorrhages in many organs were a common feature. The lungs were usually congested, and often there was focal intraalveolar haemorrhage. The kidneys were usually normal, though some degree of acute tubular necrosis was seen in three cases. Adrenal haemorrhage and infarction was noted in four cases, and in one case there was infarction of the pituitary gland.

In 13 cases the brain was soft and/or swollen and in five of these there was cerebellar herniation; the three babies whose brains were not swollen had all died early in the illness.

Changes in the small gut were reported in three cases: in one, a degree of villous blunting, in the second, partial villous atrophy with crypt abscess formation, and in the third, an increase in acute inflammatory cells. In one baby aged 3 weeks, the youngest in the series, the only abnormality was in the macroscopic appear- 
ance of the large bowel, which was described as 'consistent with haemorrhagic colitis'. In this patient shock and encephalopathy had preceded bloody diarrhoea and she met the criteria for inclusion in group $\mathrm{A}$.

The hepatic findings are described below in some detail in view of the interest in distinguishing HSES from Reye's syndrome (see discussion).

The macroscopic appearance of the liver was described as normal in only three of the 16 cases. Among the remainder it was 'pale', 'yellow' and/or 'fatty' $(n=11)$; 'congested' $(n=1)$; 'mottled reddish-brown' $(n=1)$. There were abnormalities in all 13 livers examined histologically. In five of these, all group A, fatty changes were described: in one, the fat occurred throughout the lobule, but was reported 'insufficient for Reye's syndrome'; in another it was a diffuse microvesicular infiltration 'in keeping with a Reye-like syndrome'; in the third it was described as an 'extreme degree of fatty change'; in the fourth it was periportal; in the last it was 'widespread with small and medium sized vesicles not displacing hepatocyte nuclei and not typical of Reye's syndrome'. In three of these five cases hepatic cell necrosis was also reported: centrilobular in two, widespread and focal in one.

Necrosis was also reported in three further group A cases: centrilobular in one; widespread ('therefore not Reye's') in another and as 'massive infarction leaving only periportal cell remnants' in the third.

Overall, of the nine patients who had survived more than 48 hours and whose livers were examined histologically, six showed necrosis, and four had concomitant fatty changes. Of the four who had survived less than 48 hours, none showed necrosis and one showed fatty change.

There was no relationship between plasma ammonia concentrations and hepatic fatty changes.

Electron microscopy of liver tissue was available for only one patient and showed poor cellular preservation, 'blown' mitochondria, lysosomes containing dense areas, but no other distinctive features.

\section{Discussion}

This series of cases of HSES, ascertained by routine surveillance, had certain advantages over series reported from referral centres: it enabled epidemiological trends to be assessed; it represented a wider spectrum of the condition because it was not limited to cases severe enough to merit referral; and it allowed the evolution of a rapidly developing illness to be described from its outset.

The data confirmed other reports that most patients with HSES are aged between 3 and 4 months. ${ }^{1425}$ It has been proposed by Chaves Carballo $e$ al that HSES should not be diagnosed beyond the age of 1 year. ${ }^{17}$ However, two of the patients, one in each group, were aged nearly 2 and nearly 3 years respectively, and older cases have also been described by others. $\begin{aligned} & 5 \\ & 7\end{aligned} 15242628$

The overall male excess and higher mortality among females in the previous survey ${ }^{26}$ was not seen among the 1985-8 cases. As in the earlier series, however, there was neither a distinct seasonal pattern (apart from a slight excess of cases in the winter months) nor any obvious place-time clusters.

The high rate $(13 \%)$ of previously existing developmental anomalies and problems in these patients was also observed in the 1982-4 series ${ }^{26}$ and by Levin $e t$ al, who noted such disorders in seven of their 25 patients, including two with Down's syndrome. ${ }^{24}$ Furthermore, four of the oldest five infants in the 1985-8 survey had neurodevelopmental problems. These observations are unexplained, but may represent reduced ability to respond to a harmful stimulus because of impairment either of intrinsic mechanisms or of protective behavioural responses.

A mild prodromal illness was frequently but not invariably reported. Information was incomplete, but at least three babies who had no prodrome had been immunised in the preceding 72 hours. Given the frequency with which such symptoms and events occur in infants, however, their significance in the pathogenesis of HSES is uncertain. Despite extensive investigation, no microbiological aetiological agents, including 'exotic' viruses, have been consistently isolated from patients with HSES. ${ }^{24}$ Positive microbiological findings in the current series were varied and were considered to be either non-contributory or contaminants.

As in previous descriptions, ${ }^{14-25}$ a high temperature was initially observed in most $(86 \%)$ of the patients reported to this survey, $14 \%$ having an admission temperature over $42^{\circ} \mathrm{C}$. By contrast some babies had subnormal temperatures, but all of these had been stripped for some time. One baby was described as 'very, very hot to the touch' when found by her parent and the temperature was $41.6^{\circ} \mathrm{C}$ on admission, but had fallen to $32^{\circ} \mathrm{C} 10$ hours later. A similar decline in temperature from high pyrexia on arrival at a casualty department to hypothermia after transfer to an intensive care unit some hours later, has been observed by others. ${ }^{16}$ These observations suggest that temperature control may be impaired in HSES (perhaps because of preceding pyrexial insult to the hypothalamus) and illustrate how a normal or low admission temperature could be compatible with preceding fever.

Reports from tertiary referral centres have described death or brain damage as the usual outcome of HSES. ${ }^{17} 24$ Among the 52 cases in this unselected series, six (12\%) were reported to have survived intact, though there is still the possibility that sequelae may have emerged after longer follow up.

It has been questioned whether HSES is a distinct clinicopathological entity in its own right, or whether it represents the final common pathway of several disorders with similar features. ${ }^{29}$ Although there is no single clinical or pathological factor that is pathognomonic for HSES, the pattern of features found in the present series (the largest yet described) and in others $^{4-26}$ is markedly consistent.

HSES can therefore, we believe, be distinguished from other conditions that share some of its features. The main differential diagnoses 
are septicaemia, overwhelming viraemia, Reye's syndrome, haemolytic uraemic syndrome, staphylococcal toxic shock syndrome, and various inherited disorders.

The presenting features of high fever, shock, and leucocytosis usually (and reasonably) prompt a presumptive diagnosis of septicaemia. If blood cultures are not taken before antibiotic treatment is begun, it is then difficult to exclude this diagnosis as many of the features of HSES, such as disseminated intravascular coagulation and renal failure, could be attributed to it. HSES may, therefore, be misdiagnosed as septicaemia, through either failure to take cultures before treatment or disregard of negative reports. While tropical viruses such as dengue might cause confusion with HSES, no viral infection of temperate climates, however severe and overwhelming, causes the same constellation of features

The combination of cerebral and hepatic disorder, especially when accompanied by hypoglycaemia and hyperammonaemia, inevitably suggests Reye's syndrome. Indeed some authors have suggested that HSES should not be diagnosed if one or both of these biochemical abnormalities are present. ${ }^{17} 24$ However, Reye's syndrome differs from HSES in a number of clinical and pathological details.

In Reye's syndrome the onset of illness is usually slower, with vomiting a prominent feature, while diarrhoea (especially if bloody) and disseminated intravascular coagulation are unusual. Patients with typical Reye's syndrome are considerably older (median age 8-9 years ${ }^{30}$ ) than those with HSES; where cases in infancy have been described some may have been confused with HSES.

The hyperammonaemia found in several of the patients in the present series was not as pronounced as that typically found in Reye's syndrome and there was a rapid reversion towards normal concentrations. Hyperammonaemia may be a non-specific accompaniment of severe illness and, moreover, ammonia assays are not always reliable when undertaken by laboratories not performing them regularly. Hypoglycaemia is similarly non-specific: it was a more prominent feature in the $1985-8$ cases than in some series ${ }^{124}$ but has been reported by others. 571623

Hepatocellular enzymes are increased to a similar degree in both disorders, but liver histology, with experienced interpretation, should be distinctive. Fatty change is always present in the acute phase of Reye's syndrome, persists for about five days and is typically diffuse, with panlobular microvesicular infiltration of hepatocytes, retention of nuclear position, and no necrosis or inflammatory infiltrates. ${ }^{30}$ Fatty change was reported in five of the 13 HSES patients whose livers were examined histologically, but in only one of these was it described as consistent with Reye's syndrome. The illness duration was less than five days in all of this group.

Although the hepatic histological changes in Reye's syndrome are also seen in some other conditions, ultrastructural changes appear to be pathognomonic. ${ }^{30}$ There is little published information on hepatic ultrastructural changes in HSES. ${ }^{7}$ Electron microscopic examination could be useful in distinguishing it from Reye's syndrome for those cases with fatty livers, but this is best undertaken on antemortem biospy material, which may limit the feasibility of this approach.

The combination of bloody diarrhoea, renal failure, and disseminated intravascular coagulation may lead to confusion with haemolytic uraemic syndrome. However, in haemolytic uraemic syndrome the onset of the condition is usually less abrupt, diarrhoea precedes rather than accompanies the main illness, encephalopathy, if present, comes late, and liver function is seldom disturbed.

Staphylococcal toxic shock syndrome presents with the same abruptness as HSES and shares the features of high fever, shock, and multisystem involvement. However, there is invariably a rash, not seen in HSES, and a focus of infection is usually evident (the scanty growth of staphylococci in three of our cases was attributed to contamination). Streptococcal toxic shock syndrome is a newly emerging entity which may not always be associated with a rash. It has mostly been described in adults and again there is usually an obvious focus of infection. Group A $\beta$ haemolytic streptococci were not isolated from any of the patients with HSES.

Various genetic disorders such as malignant hyperpyrexia and inborn errors of metabolism including disorders of ketogenesis, urea cycle disorders, and organic acidurias may present with sudden onset of encephalopathy in infancy or childhood. However, except in malignant hyperpyrexia, high fever is not normally a presenting feature. There may be a suggestive family or personal history, which was not recorded for any of the patients with HSES in the current series (in contrast to the 1982-4 survey ${ }^{26}$ ) except the two whose twin died the same night.

The simultaneous occurrence of HSES and SIDS in the pairs of twins in this series supports speculation about a link between the two conditions. ${ }^{1125}$ Other features supporting such a link are a similar age range, the modal age for HSES coinciding with the second peak of the bimodal distribution for SIDS, and the slight excess in the winter months. Among babies who are classified as having had an 'acute life threatening event' there may be some who have in fact had HSES.

In the absence of an established cause for HSES, explanation of its pathological features remains speculative. We suggest that most (if not all) may best be explained as secondary phenomena following a severe initial insult that affected many tissues.

Various stimuli, not necessarily infective, may cause leucocytosis and also trigger disseminated intravascular coagulation, thereby producing a rapid fall in haemoglobin and platelets. The severe acidosis of HSES is mainly metabolic and may arise initially from poor tissue perfusion and then from renal failure.

Hypoglycaemia was an unexpected and interesting finding; it may have resulted from sudden hepatic dysfunction, but its refractoriness 
raises the possibility of hyperinsulinaemia. Unfortunately, no insulin assays were undertaken. Although no pancreatic damage was observed at postmortem examination, the increase of amylase and trypsin is compatible with a leak of pancreatic enzymes.

Hypernatraemia could be explained by sweating; it was found before the onset of diarrhoea, so that intestinal fluid loss is a less likely explanation. The peaking of hepatocellular enzymes at about 48 hours suggests an evolving disorder of hepatic cells that subsequently resolves. Creatine kinase and trypsin were most often found to be raised and $\alpha_{1}$-antitrypsin to be depressed at the onset of the illness and then to revert to normal, suggesting that these were secondary rather than causative features.

Postmortem findings were generally nonspecific and were all consistent with reduced blood flow and hypoxia secondary to hypotension. Cerebral oedema may result from a variety of insults, while acute renal tubular necrosis and hepatic centrilobular necrosis may both follow circulatory failure. Widespread petechial haemorrhages are commonly found in babies dying from SIDS and are also often found at postmortem examination when there has been hypoxic capillary endothelial damage while the circulation continues. Changes in small gut histology similar to those found in four of the cases have been associated with overheating in one report, ${ }^{3}$ but were regarded as non-specific in another. ${ }^{31}$

Several authors have commented on the close similarity between the clinical and pathological features of HSES and those of heat stroke. ${ }^{2} 7101216173233$ The most detailed descriptions of heat stroke are of soldiers in hot climates, ${ }^{34} 35$ but there are also some of babies left in cars in the sun, ${ }^{36} 37$ who appear to be affected in the same way as adults. Such patients present with acute encephalopathy (convulsions, altered consciousness), initial profuse sweating, shock, diarrhoea, renal failure, hypernatraemia, metabolic acidosis, clotting disturbance, thrombocytopenia, and raised hepatic transaminases. Illness severity may be determined not only by the thermal environment but also by individual susceptibility, ${ }^{34}$ the nature of which is not yet understood.

Pathological features, also described in patients given hyperthermia therapy, ${ }^{38}$ include cerebral oedema, characteristic changes in the dentate nucleus, Purkinje cells, and Bergmann astrocytes; hepatocellular necrosis and fatty change (both dependent on illness duration); and diffuse multiorgan petechial haemorrhages.

There have also been reports from France, ${ }^{39}$ India ${ }^{40}$ and England ${ }^{3}$ of infants and young children presenting with an illness identical to heat stroke, but lacking a clear cut history of overheating. The authors suggest that heat injury may nevertheless have been the cause if the effects of an initial febrile illness were compounded by excessive insulation (in the European cases) or by very high ambient temperature (in the Indian).

The similarity of these cases and of HSES to classical heat stroke supports the hypothesis that all these disorders may be one and the same. Biochemical abnormalities reported in HSES, but not in heat stroke, such as raised serum trypsin and reduced $\alpha_{1}$-antitrypsin, may not yet have been sought in the latter condition. It is possible that they are among many epiphenomena that follow an initial global insult. To date there appear to have been no reports in HSES of the specific changes in brain histology noted in heat stroke; it is possible that they, too, have not been sought.

One group has reported finding botryoid nuclei in peripheral white blood cells (said to be specific for heat stroke) in two HSES patients on admission, but not 24 hours later. ${ }^{10}$ They were not noted among any of the patients in the present series, but again were probably not specifically sought within the critical time period.

Other authors have expressed scepticism about the relationship between HSES and heat stroke, mainly because of the apparent absence either of a history of overheating or of a very high temperature on admission. ${ }^{49} 242541$ Admission temperature is, however, an unreliable indicator of preceding hyperpyrexia and specific details of the infant's home thermal environment are necessary to elicit the possibility of overheating. ${ }^{42}$ These should include the temperature of the infant's bedroom, the insulation provided by the clothing and bedding (preferably estimated in tog values), whether the head was covered, and whether the baby was hot and sweaty when first found.

Other aetiopathogenic theories, for example that HSES results from deficiencies of protease inhibitors, ${ }^{24}$ abnormalities in stress protein production, ${ }^{25}$ or bacterial endotoxin leaking through a gut lining damaged by splanchnic ischaemia, ${ }^{18}$ are all compatible with the notion that the pathogenic cascade of events culminating in HSES results from a heat induced trigger in a genetically determined, susceptible individual. The rarity of HSES could be compatible with this hypothesis, because an improbable combination of risk factors would have to be present to initiate the cascade. It would also explain the characteristic age range (a time of life when both thermoregulation is immature and maternally derived immunity is waning) and would be compatible with the occasional case occurring in older children-a similar pattern is seen in some of the infection-precipitated Reye-like metabolic disorders. The highly significant clustering of admission times (unlikely to be confounded by administrative factors in such severe illness) also supports this hypothesis-it suggests a peak onset period at night, a time when a baby may be most at risk from heat injury. ${ }^{43}$ If HSES is, therefore, the result of heat injury, then it is not a new disease. However, recent fashions in bedroom heating and babies' bedding and clothing may pose new risk factors for the condition.

In the absence of a clear understanding of the aetiopathogenesis of HSES, management has to be non-specific and supportive. The current survey did not aim formally to evaluate treatment, which essentially is a salvage operation after the initial catastrophic event preceding presentation. The variety of measures used were 
dictated by the course of the illness. It was not possible to demonstrate that any had a consistent beneficial effect, although early vigorous measures to counter cerebral oedema appeared to be associated with improved outcome.

We agree with others, that the term 'haemorrhagic' shock is misleading, because it implies that shock ensues from haemorrhage, whereas in fact it precedes it. ${ }^{44}$ As abrupt onset is invariable, we suggest that if a change of title is contemplated, 'acute shock encephalopathy syndrome' might be more appropriate. Alternatively, if the condition is indeed a form of heat stroke another title is unnecessary.

We propose that the diagnoses of HSES be made on the basis of the features specified in our case definition, plus the exclusion of the similar disorders discussed above. We do not agree that an upper age limit of 1 year should be set or that patients with hypoglycaemia and hyperammonaemia should be excluded. We further suggest that clinical and pathological observations in future series should be reported in relation to the interval after onset, and that there is a need for more detailed and systematic histological and ultrastructural studies, particularly of brain and liver.

In conclusion, the data from this CDSC/BPA surveillance scheme do not suggest that HSES was a major new and increasing public health problem in the British Isles in the 1980s, associated with some novel environmental agent. However, although the disease is uncommon it is so severe that further studies to elucidate its aetiopathogenesis are essential, especially as the possibility of a preventable cause, namely hyperthermia, has been raised.

We thank the paediatricians who reported cases and who gave permission to review case notes and include their patients in the surveillance scheme. We wish to acknowledge Dr Jean Keeling for her helpful comments on the manuscript. We also thank the British Paediatric Surveillance Unit, which is generously supported by the Children Nationwide Medical Research Fund.

1 Levin M, Kay JDS, Gould JD, et al. Haemorrhagic shock and encephalopathy: a new syndrome with a high mortality in young children. Lancet 1983;ii:64-7.

2 Aujard Y, Beaufils F, Bourrilon A, Huault D. Hyperthermi majeure de l'enfant. Arch Fr Pediatr 1978;35:477-85.

Bacon C, Scott D, Jones P. Heatstroke in well-wrapped infants. Lancet 1979; : $422-5$

4 Lafeber HN, vd Voort E, de Groot R. Haemorrhagic shock and encephalopathy syndrome. Lancet 1983;ii:795.

5 Hervàs JA, Masip MC, Caimari M, Reynés J. Further observations in haemorrhagic shock and encephalopathy vations in haemorrhagic shock and encephalop
syndrome. Helvetica Paediatra Acta 1986;41:469-71.

6 Van Acker KJ, Roodhooft AM, Van Bever H. Haemorrhagic shock and encephalopathy. Eur $\mathcal{F}$ Pediatr 1986;145:66-9.

shock and encephalopathy. Eur $\mathcal{F}$ Pediatr 1986;145:66-9.
7 Heinrichs C, Tabardel Y, Frikiche A, et al. Le syndrome de choc hémorragique avec encéphalopathie: un nouveau choc hémorragique avec encéphalopathie: un nouveau
syndrome? A propos de 2 cas. Rev Med Liege 1988;XLIII: syndrome

8 Roth B, Younossi-Hartenstein A, Schröder R, et al. Haemorrhagic shock-encephalopathy syndrome: plasmapheresis as a therapeutic approach. Eur $\mathcal{F}$ Pediatr 1987;146: 83-5.

9 Kirschstein M, Aksu F, Tegtmeyer F. Häemorrhagisches Schock und Enzephalopathiesyndrom im Sauglings-und Kindesalter. Monatsschr Kinderheilkd 1991;139:105-9.

10 Neves JF, Lopes D, Casal MI, et al. 'Botryoid nuclei' of leucocytes in the haemorrhagic shock and encephalopathy syndrome. Lancet 1988; 1112
11 Nelson EAS, Taylor BJ, Dempster AG. Haemorrhagic shock encephalopathy syndrome. $N Z$ Med $\mathcal{F}$ 1988;101:69-71

12 Sofer S, Phillip P, Hershkowits J, Bennett H. Hemorrhagi shock and encephalopathy syndrome. Its association with hyperthermia. Am $\mathcal{f}$ Dis Child 1986;140:1252-4.

13 Schrager GO, Shah A. Haemorrhagic shock encephalopathy syndrome in infancy. Lancet 1983;ii:396.

14 Whittington LK, Roscelli JD, Parry WH. Haemorrhagic shock and encephalopathy: further description of a new syndrome. I Pediatr 1985;106:599-602.

15 Caspe WB, Nucci AT, Cho S. Extreme hyperpyrexia in childhood. Presentation similar to hemorrhagic shock and childhood. Presentation similar to hemorrhagic shock

16 Weibley RE, Pimentel B, Ackerman NB. Hemorrhagic shock and encephalopathy syndrome of infants and children. Cri Care Med 1989;17:335-8.

17 Chaves-Carballo E, Montes JE, Nelson B. Chrenka BA Hemorrhagic shock and encephalopathy. Clinical definition of a catastrophic syndrome in infants. Am F Dis Child 1990 144:1079-82.

18 Conway EE, Varlotta L, Singer LP, Caspe WB. Hemorrhagic shock and encephalopathy: is it really a new entity? Pediatr Emerg Care 1990;6:131-4.

19 Tam, AYC, Ng IOL, Cheng PT, Tang TS, Li CH. Haemorrhagic shock encephalopathy. Acta Paediatr Scand 1989;78: 458-62.

20 Chiu NC, Shen EY, Lee HC. Haemorrhagic shock and encephalopathy syndrome: report of two cases Acto Paediatr Sin 1989;30:118-21.

21 Morris JA, Matthews TS. Haemorrhagic shock and encephalopathy:a new syndrome in young children. Lance halopathy:a
1983;ii: 278

22 McGucken RB. Haemorrhagic shock and encephalopathy syndrome. Lancet 1983;ii:1087.

23 Mughal MZ, Wells FE, Addison GM, Heeley AF. Raised serum immunoreactive trypsin in the haemorrhagic shock and encephalopathy syndrome. Acta Paediatr Scand 1985 74:456-7.

24 Levin M, Pincott JR, Hjelm M, et al. Hemorrhagic shock and encephalopathy: clinical, pathologic and biochemical features. F Pediatr 1989;114:194-203.

25 Trounce JQ, Lowe J, Lloyd BW, Johnston DI. Haemorrhagic shock encephalopathy and sudden infant death. Lancet 1991;337:202-3.

26 Joint British Paediatric Association and Communicable Disease Surveillance Centre surveillance scheme for Disease Surveillance Centre surveillance scheme for haemorrhagic shock encephalopathy syndr
report for 1982-4. BMF 1985;290:1578-9.

27 Hall SM, Glickman M. The British Paediatric Surveillance Unit. Arch Dis Child 1988;63:344-6.

28 Dupee CR. Hyperpyrexia, hemorrhagic shock and encephalopathy, and creatinine phosphokinase. Am $\mathcal{J}$ Dis Child 1991;145:719.

29 Anonymous. Haemorrhagic shock encephalopathy syndrome [Editorial]. Lancet 1985;ii:534-6.

30 Partin JS. Ultrastructural changes in liver, muscle and brain in Reye's syndrome. In: Wood C, ed. Reyes syndrome. RSM Round Table Series 8. London: Royal Society of Medicine, 1988:1-19.

31 Variend S, Sunderland R. Small intestinal mucosal abnormalities in post-perinatal deaths. 7 Clin Pathol 1984;37: 283-7.

32 Stanton AN. Haemorrhagic shock and encephalopathy. Lancet 1985; ii: 1019-20.

33 Bass $M$. The fallacy of the hemorrhagic shock and encephalopathy syndrome. Am 7 Dis Child 1991;145:718.

34 Shibolet S, Coll R, Gilat T, Sohar E. Heatstroke: its clinical picture and mechanism in 36 cases. $Q \mathcal{F}$ Med 1967;144: 525-48.

35 Malamud N, Haymaker W, Custer RP. Heatstroke: a clinico pathologic study of 125 fatal cases. Military Surgeon 1946 99:397-449.

36 King K, Negus K, Vance JC. Heat stress in motor vehicles: problem in infancy. Pediatrics 1981;68:579-82.

37 Wadlington WB, Tucker AL, Fly F, Greene HL. Heat stroke in infancy. Am $\mathcal{F}$ Dis Child 1976;130:1250-

38 Wills EJ, Findlay JM, McManus JPA. Effects of hyperthermia therapy on the liver. II Morphological observations. $\mathcal{F}$ Clin Pathol 1976;29:1-10.

39 Beaufils F, Aujard Y, Huault G. Prévention du syndrome d'hyperthermie majeure du nourrisson. Arch Fr Pediatr d'hyperthermie
1976;33:161-6.

40 Sriramachari S, Patoria NK. Pathology of acute encephalopathy syndrome in children in summer. Indian $\mathfrak{f} \mathrm{Med} R \mathrm{Re}$ 1976;64:296-313.

41 David TJ, Mughal MZ. Haemorrhagic shock and encephalopathy syndrome: epidemic of a new disease. $\mathcal{F} R$ Soc Med 1984;77:721-2.

42 Bacon CJ. Haemorrhagic shock encephalopathy and sudden infant death. Lancet 1991;337:1048.

43 Bacon CJ, Bell SA, Clulow EE, Beattie AB. How mother keep their babies warm. Arch Dis Child 1991;66:627-32.

44 Corrigan JJ. The ' $\mathrm{H}$ ' in hemorrhagic shock and encephalopathy syndrome should be 'hyperpyrexia' [Editorial]. Am Dis Child 1990;144:1077. 